Article

\title{
Poly- $\gamma$-Glutamic Acid: Biodegradable Polymer for Potential Protection of Beneficial Viruses
}

\author{
Ibrahim R. Khalil ${ }^{1,2, *}$, Victor U. Irorere ${ }^{1}$, Iza Radecka ${ }^{1}$, Alan T. H. Burns ${ }^{1}$, \\ Marek Kowalczuk ${ }^{1,3}$, Jessica L. Mason ${ }^{1}$ and Martin P. Khechara ${ }^{1, *}$ \\ Received: 16 November 2015; Accepted: 21 December 2015; Published: 6 January 2016 \\ Academic Editor: Carla Renata Arciola \\ 1 Faculty of Science and Engineering, University of Wolverhampton, Wulfruna Street, \\ Wolverhampton WV1 1LY, UK; Irorere-V@email.ulster.ac.uk (V.U.I.); I.Radecka@wlv.ac.uk (I.R.); \\ A.T.Burns@wlv.ac.uk (A.T.H.B.); M.Kowalczuk@wlv.ac.uk (M.K.); J.Mason@wlv.ac.uk (J.L.M.) \\ 2 Department of Biology, College of Science, Tikrit University, Tikrit PO Box 42, Iraq \\ 3 Center of Polymer and Carbon Materials, Polish Academy of Sciences, ul. M. Curie-Skłodowskiej 34, \\ Zabrze 41-819, Poland \\ * Correspondence: Ibrahim.khalil@wlv.ac.uk (I.R.K.); mpkhechara@wlv.ac.uk (M.P.K.); \\ Tel.: +44-01902-32-3538 (M.P.K.); Fax: +44-01902-32-2714 (M.P.K.)
}

\begin{abstract}
Poly- $\gamma$-glutamic acid ( $\gamma$-PGA) is a naturally occurring polymer, which due to its biodegradable, non-toxic and non-immunogenic properties has been used successfully in the food, medical and wastewater industries. A major hurdle in bacteriophage application is the inability of phage to persist for extended periods in the environment due to their susceptibility to environmental factors such as temperature, sunlight, desiccation and irradiation. Thus, the aim of this study was to protect useful phage from the harmful effect of these environmental factors using the $\gamma$-PGA biodegradable polymer. In addition, the association between $\gamma$-PGA and phage was investigated. Formulated phage (with $1 \% \gamma$-PGA) and non-formulated phage were exposed to $50{ }^{\circ} \mathrm{C}$. A clear difference was noticed as viability of non-formulated phage was reduced to $21 \%$ at $\log _{10} 1.3 \mathrm{PFU} / \mathrm{mL}$, while phage formulated with $\gamma$-PGA was $84 \%$ at $\log _{10} 5.2 \mathrm{PFU} / \mathrm{mL}$ after $24 \mathrm{~h}$ of exposure. In addition, formulated phage remained viable at $\log _{10} 2.5 \mathrm{PFU} / \mathrm{mL}$ even after $24 \mathrm{~h}$ of exposure at $\mathrm{pH} 3$ solution. In contrast, non-formulated phages were totally inactivated after the same time of exposure. In addition, non-formulated phages when exposed to UV irradiation died within $10 \mathrm{~min}$. In contrast also phages formulated with $1 \% \gamma$-PGA had a viability of $\log _{10} 4.1 \mathrm{PFU} / \mathrm{mL}$ at the same exposure time. Microscopy showed a clear interaction between $\gamma$-PGA and phages. In conclusion, the results suggest that $\gamma$-PGA has an unique protective effect on phage particles.
\end{abstract}

Keywords: biodegradable polymer; $\gamma$-PGA; bacteriophage

\section{Introduction}

Poly- $\gamma$-glutamic acid is a naturally occurring polymer synthesized by various microbial strains especially Bacillus species [1,2]. It is a homopolyamide, composed of glutamic acid monomers connected by amide linkages between $\alpha$-amino and $\gamma$-carboxyl groups. The polymer $\gamma$-PGA can be obtained in either $\mathrm{L}$ or $\mathrm{D}$ or both $\mathrm{L}$ and $\mathrm{D}$ isomeric forms depending on the bacterial strain or on the productive media employed in its production. This polymer can be water insoluble (free acid form) or completely water soluble as its salt form with a variety of cations $\left(\mathrm{Na}^{+}, \mathrm{Mg}^{2+}, \mathrm{K}^{+}, \mathrm{NH}^{4+}\right.$ or $\left.\mathrm{Ca}^{2+}\right)[3-5]$. $\gamma$-PGA has been used widely in drug delivery platforms, because it has carboxyl groups on the side chains, this group offers attachment points for the conjugation of chemotherapeutic agents; thus making the drug more soluble and easy for controlled release. It has also been used for protein and vaccine encapsulation, immobilization or adsorption for delivery to specific action sites [6-8]. Although 
no report of viral $\gamma$-PGA interaction was found in the literature, the encapsulation or immobilization of vaccines with this biodegradable polymers and its use in the protection of probiotic bacteria from harsh environmental conditions [7-10] suggest that $\gamma$-PGA can be used as an immobilization or encapsulating agent for bacteriophage to offer protection from harmful environmental conditions.

Bacteriophages (phages) are viruses that invade specific bacteria. Virulent or lytic phages infect and kill their hosts. Their high specificity and rapid killing kinetics against their target species plus their safety profile make them particularly attractive antibacterial natural products [11,12]. Antibiotic resistance of bacterial pathogens is presently a source of major concern to modern medicine and its incidence has grown sharply in recent years $[13,14]$. As a result, improving phage therapy may represent an important step in the fight against these resistant bacteria. There are many advantages in the use of phage for biological control. For instance, the specificity of some phages to a single bacterial species, or even strain allows safe targeting to the pathogenic bacteria without causing any harm to the normal flora when used for therapeutic purposes. Secondly, their low cost of production and ability to proliferate once inside their target cell makes them suitable antibacterial agents with regards to both economic cost and dosage [15-18]. Furthermore, they have a high success rate against the target organism with no reports of harmful side effects to humans to date [19,20].

However, the ability of phage to persist for extended periods is limited by many factors, particularly environmental factors such as sunlight, irradiation (UV irradiation), temperature, desiccation, and exposure to copper bactericides [21-24]. High temperature directly affects the amino acids of bacteriophage, by fracturing their bonds and denaturing the proteins of the phage particle $[20,21]$ while UV radiation results in direct DNA damage by causing lesions in cellular DNA that consequently obstruct RNA transcription and DNA replication [24]. It is, therefore, necessary that methods be developed to protect phages from these environmental factors in order to improve their persistence in the environment for efficient storage and potential use as topical or environmental antibacterial agents. Previously, we have shown that the biodegradable polymer poly- $\gamma$-glutamic acid ( $\gamma$-PGA) can be used to protect beneficial bacteria from various environmental factors during their various stages of preparation, storage and ingestion $[9,10]$. We therefore hypothesized that this polymer could also be applied in bacteriophage protection from harmful environmental factors. Thus, this research was aimed at investigating the survival of bacteriophage under different environmental conditions when protected with $\gamma$-PGA.

\section{Results}

\subsection{Identification of $\gamma-P G A$}

FT-IR and ${ }^{1} \mathrm{H}-\mathrm{NMR}$ spectroscopies were used in the identification of the $\gamma$-PGA produced. The spectrum shown is a mean of 3 spectra. The IR spectra (Figure 1) gave peaks specific to $\gamma$-PGA [1] with the strong amide absorption seen at wavenumbers of $1620.52\left(\mathrm{~cm}^{-1}\right)$. The peaks at $1407.78\left(\mathrm{~cm}^{-1}\right)$ and $1055.84\left(\mathrm{~cm}^{-1}\right)$ are representative of $\mathrm{C}=\mathrm{O}$ and $\mathrm{C}-\mathrm{N}$ groups respectively while the stretch seen at $\sim 3293\left(\mathrm{~cm}^{-1}\right)$ is representative of the hydroxyl group.

Also the ${ }^{1} \mathrm{H}-\mathrm{NMR}$ spectrum (Figure 2) confirms the sole presence of $\gamma$-PGA in the synthesized samples. $X$ indicates impurity peaks and the extraordinary high peak is the Deuterium Oxide $\left(\mathrm{D}_{2} \mathrm{O}\right)$ used as a solvent. The number average molecular mass $\left(\mathrm{M}_{n}\right)$ analyzed by GPC was 482,000 and dispersity was 1.3 . 


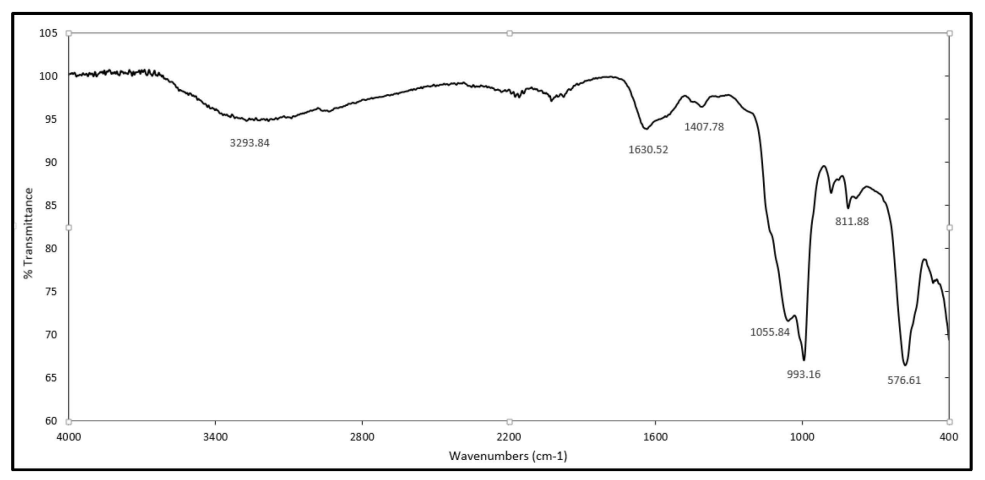

Figure 1. FT-IR absorption spectrum of $\gamma$-PGA produced by B. subtilis natto in G.S medium. The spectrum is the mean of 3 spectra.

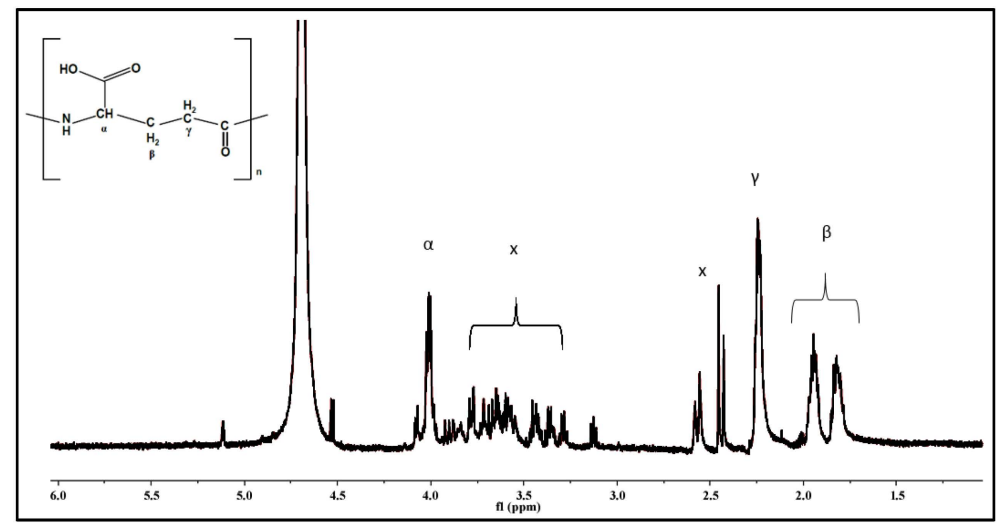

Figure 2. ${ }^{1} \mathrm{H}$-NMR spectrum of $\gamma$-PGA. The peak $4.7 \mathrm{ppm}$ corresponds to the $\mathrm{D}_{2} \mathrm{O}$ used as a solvent. $\mathrm{X}$-marked peaks indicate impurity peaks, most of which are amino acids residues.

\subsection{Effect of Temperature on Formulated and Non-Formulated Phage}

The survival rate of formulated and non-formulated phage was evaluated via a series of time course experiments at different temperatures. The effect of $\gamma$-PGA concentration on the viability of formulated phage was initially studied at $50{ }^{\circ} \mathrm{C}$. The results obtained show an increase in viability at all incubation time with increasing concentration of $\gamma$-PGA (Figure 3). The difference in viability between $1 \%$ and $2 \%$ is however significant but with little biological relevance $(\mathrm{P} \leqslant 0.05)$. Thus, $1 \%$ $\gamma$-PGA formulation was used in subsequent experiment.

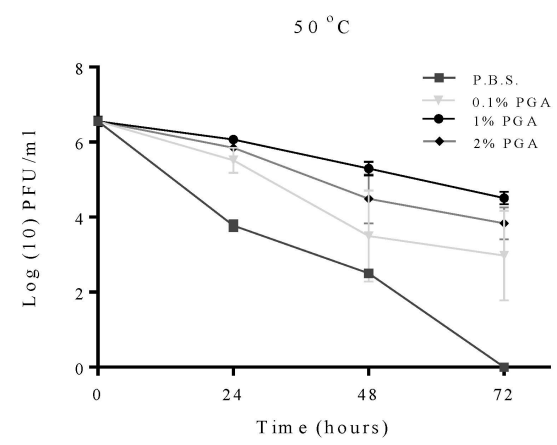

Figure 3. Effect of different concentrations of $\gamma$-PGA on MS2 viability at $50{ }^{\circ} \mathrm{C}$, over the time course of $72 \mathrm{~h}$. Experiments were conducted in quadruplicate $(n=4)$. Error bars represent the standard error of the mean. (PBS = non-formulated phage in phosphate buffered saline, used as a control; PGA = formulated phage with poly-gamma-glutamic acid). 
For the effect of increasing temperature on MS2 viability, viability of formulated and non-formulated phage at different temperatures was assessed at 24, 48 and $72 \mathrm{~h}$. The results obtained showed that at $25^{\circ} \mathrm{C}$ there was no significant change in MS2 viability under either condition (Figure 4). At $37^{\circ} \mathrm{C}$, no significant difference was observed in the viability of formulated and non-formulated phage at $24 \mathrm{~h}$ and $8 \mathrm{~h}$ while at $72 \mathrm{~h}$ the viability of formulated phage ( $\left.\log _{10} 6.4 \mathrm{PFU} / \mathrm{mL}\right) \mathrm{was}$ significantly higher than non-formulated phage ( $\left.\log _{10} 5.9 \mathrm{PFU} / \mathrm{mL}\right)$.
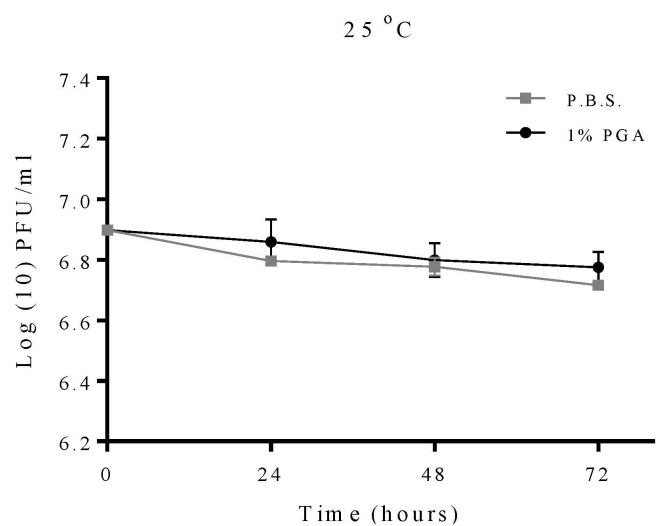

(a)

$50{ }^{\circ} \mathrm{C}$

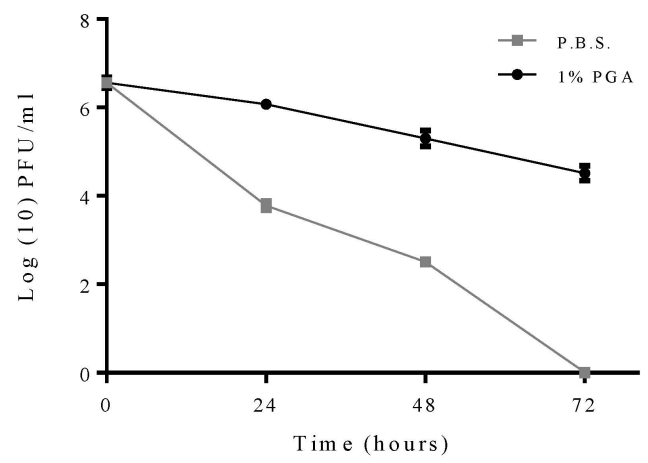

(c)

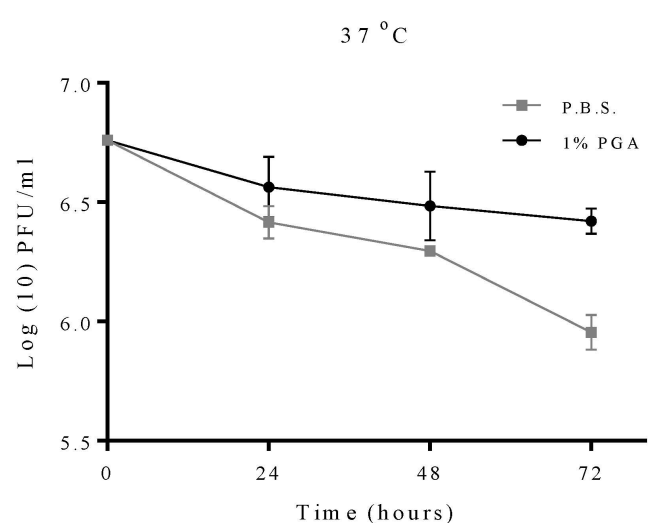

(b)
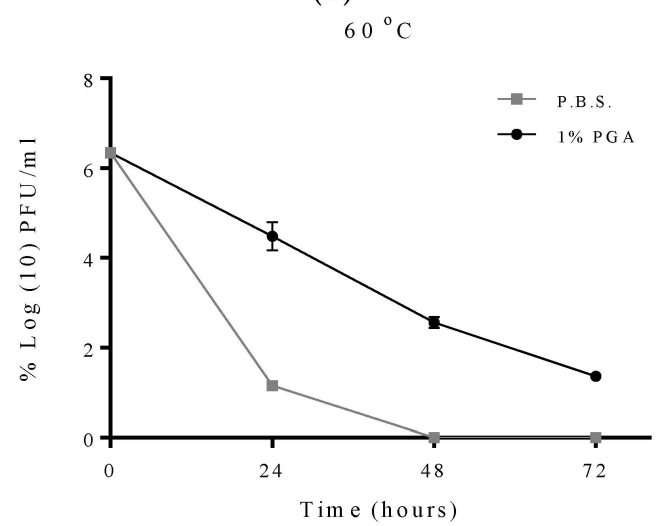

(d)

Figure 4. Protective effect of $\gamma$-PGA on MS2 phage at different temperatures. Data points were measured at 24,48 and $72 \mathrm{~h}$. All experiments were conducted in quadruplicate $(n=4)$. Error bars represent the standard error of the mean. Formulated and non-formulated MS2 phage exposed to (a) $25^{\circ} \mathrm{C}$; (b) $37^{\circ} \mathrm{C}$; (c) $50{ }^{\circ} \mathrm{C}$; (d) $60^{\circ} \mathrm{C}$.

When the incubation temperature was increased to $50^{\circ} \mathrm{C}$, significant differences can be observed in the viability of formulated and non-formulated phages from $24 \mathrm{~h}$ to $72 \mathrm{~h}$ of incubation, with a complete loss in viability observed at $72 \mathrm{~h}$ for non-formulated phage while formulated phage had a viability of $\log _{10} 5.2 \mathrm{PFU} / \mathrm{mL}$. Increasing the incubation temperature further to $60{ }^{\circ} \mathrm{C}$ reveals a similar trend to an incubation temperature of $50{ }^{\circ} \mathrm{C}$ in the differences in viability between formulated and non-formulated phage over a $72 \mathrm{~h}$ period. However, complete loss in viability was observed at $48 \mathrm{~h}$ for non-formulated phage while formulated phage had a viability of $\log _{10} 1.3 \mathrm{PFU} / \mathrm{mL}$ even after $72 \mathrm{~h}$ of incubation (Figure 4).

For T2 phage, viability of formulated and non-formulated phage was assessed at 1, 2, 3, 4, 5 and $24 \mathrm{~h}$ of incubation at the different temperature studied. At $25^{\circ} \mathrm{C}$ there was no significance difference between formulated and non-formulated T2 phage after $24 \mathrm{~h}$ of incubation (Figure 5). At $37^{\circ} \mathrm{C}$ the difference in viability between formulated $\mathrm{T} 2$ phage and non-formulated phage was significant at all time points studied. 


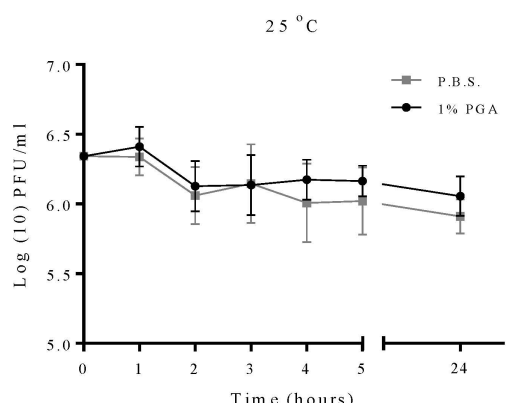

(a)

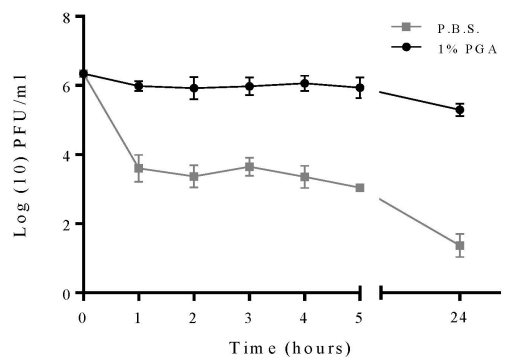

(c)

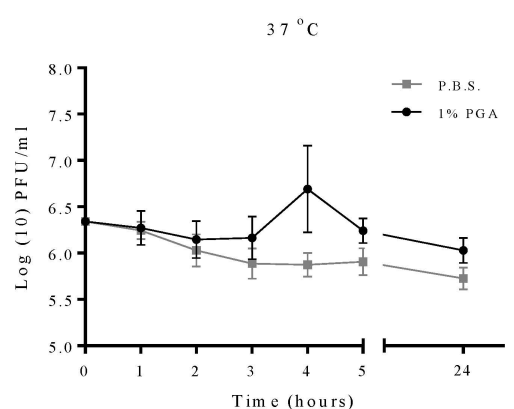

(b)

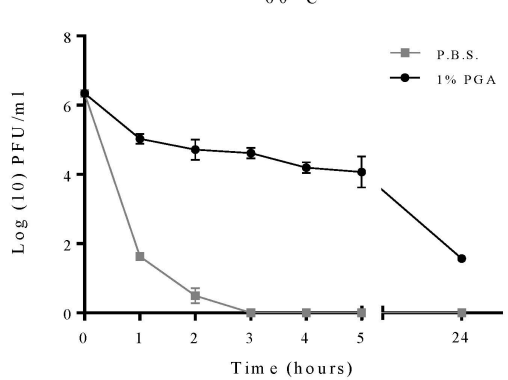

(d)

Figure 5. Effect of elevated temperature on formulated and non-formulated $\mathrm{T} 2$ phage longevity. Experiments were measured at 1, 2, 3, 4, 5 and $24 \mathrm{~h}$. All experiments were conducted in quadruplicate $(\mathrm{n}=4)$. Error bars represent the standard error of the mean. Formulated and non-formulated T2 phage exposed to (a) $25^{\circ} \mathrm{C}$; (b) $37^{\circ} \mathrm{C}$; (c) $50{ }^{\circ} \mathrm{C}$; (d) $60{ }^{\circ} \mathrm{C}$. However, at $50{ }^{\circ} \mathrm{C}$ a significant difference was observed in the viability between formulated and non-formulated phage at all time points with formulated phage having a viability of $5.3 \log _{10} \mathrm{PFU} / \mathrm{mL}$ after $24 \mathrm{~h}$ of incubation compared to non-formulated phage with a viability of $1.3 \log _{10} \mathrm{PFU} / \mathrm{mL}$, representing an $84 \%$ difference in viability. Similar results were obtained at $60{ }^{\circ} \mathrm{C}$ as the survival rate of non-formulated phage dramatically declined (Figure 5) and completely disappeared after $3 \mathrm{~h}$ while formulated phage was still viable with a survival rate of $1.5 \log _{10} \mathrm{PFU} / \mathrm{mL}$.

In order to investigate which formulation had the better protective effect, a comparison between T2 phage formulated with $\gamma$-PGA or with $0.75 \%$ skimmed milk and $0.5 \%$ sucrose as described previously [24] was conducted. Both formulations were exposed to $60{ }^{\circ} \mathrm{C}$ for $24 \mathrm{~h}$ (Figure 6). The viability of formulated phage with $\gamma$-PGA was greater than the non- $\gamma$-PGA formulation as phages formulated with $\gamma$-PGA showing $1.5 \log$ unit of viability, while the milk formulated phage was almost inactivated after $24 \mathrm{~h}$ of exposure.

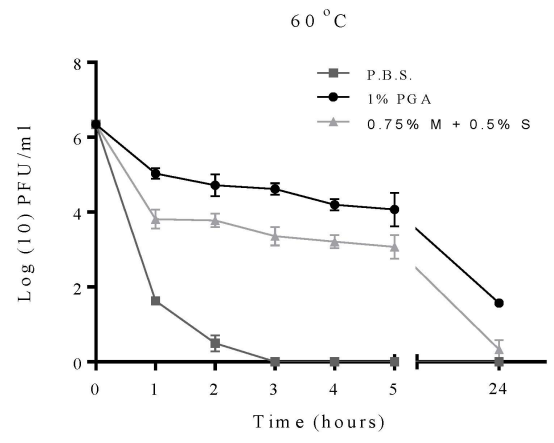

Figure 6. A comparison between formulated T2 phage with $\gamma$-PGA and formulated T2 phage with $0.75 \%$ of skimmed milk and $0.5 \%$ of sucrose $(0.75 \% \mathrm{M}+0.5 \mathrm{~S})$ after exposure to $60{ }^{\circ} \mathrm{C}$ for $24 \mathrm{~h}$. Experiments were conducted in quadruplicate $(n=4)$. Error bars represent the standard error of the mean. 


\subsection{Effects of $\mathrm{pH}$ on Formulated and Non-Formulated Phage}

The effect of $\mathrm{pH}$ on the viability of formulated and non-formulated $\mathrm{T} 2$ phage was studied using different $\mathrm{pH}$ solutions. Viability was determined at $0,24,48$ and $72 \mathrm{~h}$ of exposure except for $\mathrm{pH} 3$ where viability was determined at $0,1,2,3$ and $24 \mathrm{~h}$ of exposure as preliminary experiment showed no viability for either formulated or non-formulated phage after $48 \mathrm{~h}$ (results not shown). At $\mathrm{pH} 11$, formulated phage survived well when compared to non-formulated phage as the formulated phage population remained at $4.6 \mathrm{Log}_{10} \mathrm{PFU} / \mathrm{mL}$ after $72 \mathrm{~h}$ of exposure compared to non-formulated phage viability which was $2.3 \log _{10} \mathrm{PFU} / \mathrm{mL}$. At $\mathrm{pH} 4$, no significant reduction in viability was observed in the formulated phage throughout the $72 \mathrm{~h}$ period of exposure while non-formulated phage had a significant reduction in viability of approximately $2.5 \log _{10} \mathrm{PFU} / \mathrm{mL}$ (Figure 7). When the $\mathrm{pH}$ was reduced to 3 , a complete loss in viability was observed for non-formulated phage after $24 \mathrm{~h}$ while formulated phage still had a viability of about $2.5 \log _{10}$ PFU/mL (Figure 7).

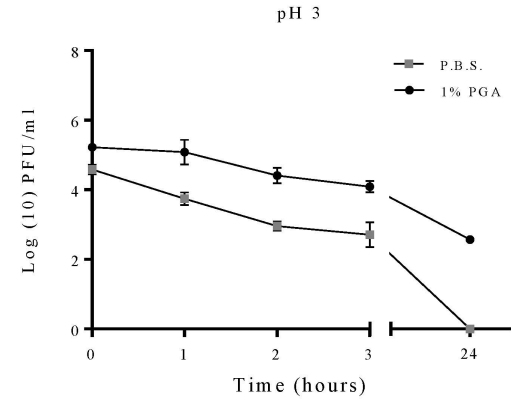

(a)

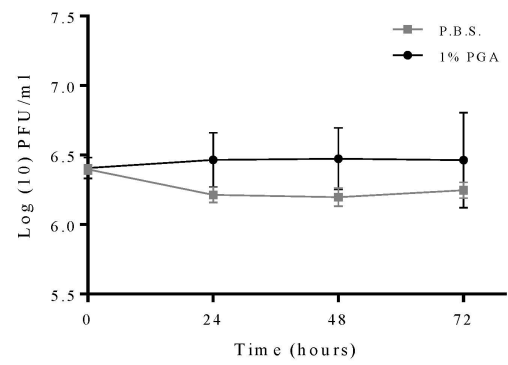

(c)

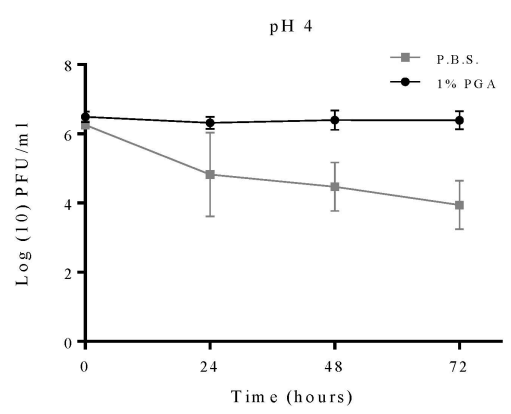

(b)

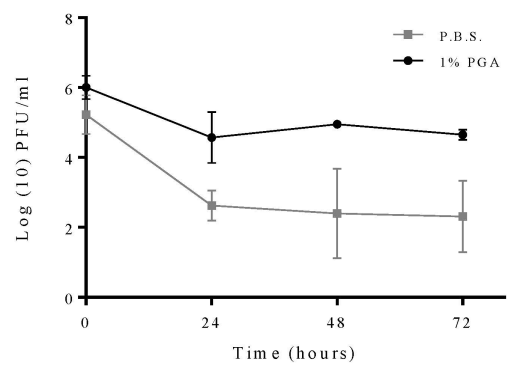

(d)

Figure 7. The protective effect of $\gamma$-PGA on T2 phage at different $\mathrm{pH}$ solutions. Experimental points measured at $0,24,48$ and $72 \mathrm{~h}$, and conducted in quadruplicate $(\mathrm{n}=4)$. Readings from the $\mathrm{pH} 3$ experiment were measured at 0, 1, 2, 3 and $24 \mathrm{~h}$. Error bars represent the standard error of the mean. Formulated and non-formulated T2 phage exposed to solution of (a) $\mathrm{pH} 3$; (b) $\mathrm{pH} 4$; (c) $\mathrm{pH} 7$; (d) $\mathrm{pH} 11$.

\subsection{Effect of UV Irradiation on Formulated and Non-Formulated Phage}

To investigate the protective effect of $\gamma$-PGA, non-formulated or formulated phage with $\gamma$-PGA were exposed to ultraviolet light (UV) for 5 and $10 \mathrm{~min}$, and viability measured with the overlay plaque assay. Formulated T2 phage showed better survival after exposure to UV irradiation compared to non-formulated phage, which showed complete loss of viability after 5 min of exposure (Figure 8a). The viability of formulated phage was above $50 \%$ at $3.2 \log _{10} \mathrm{PFU} / \mathrm{mL}$ even after 10 min of exposure to UV irradiation.

Formulated and non-formulated MS2 phages were also exposed to UV irradiation. The results obtained showed a significant decrease in viability of non-formulated MS2 to $0.8 \log _{10} \mathrm{PFU} / \mathrm{mL}$ after $5 \mathrm{~min}$ and a complete loss in viability after $10 \mathrm{~min}$ of exposure to UV irradiation. On the other hand, formulated MS2 retained viability after $10 \mathrm{~min}$ of exposure with a viability of $4.1 \log _{10} \mathrm{PFU} / \mathrm{mL}$ (Figure 8b). 
UV

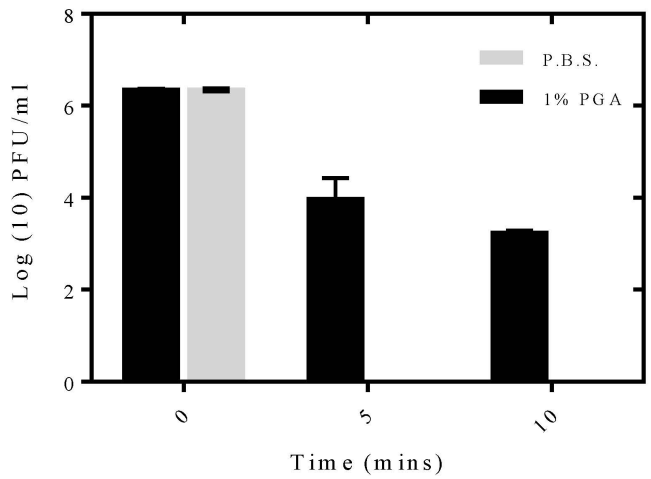

(a)
UV

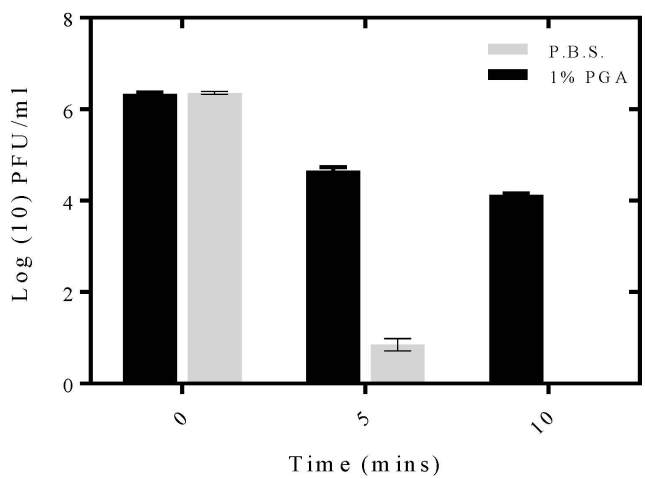

(b)

Figure 8. Effect of UV irradiation on formulated on non-formulated phage population: (a) Protective effect of $\gamma$-PGA on T2 phage; (b) Protective effect of $\gamma$-PGA on MS2 phage. Readings were measured at 0,5 and $10 \mathrm{~min}$, at a wave length of $245 \mathrm{~nm}$. All experiments were conducted in quadruplicate $(\mathrm{n}=4)$. Error bars represent the standard error of the mean.

\subsection{Formulated and Non-formulated Phage Microscopy}

In order to investigate the interaction between the phage and $\gamma$-PGA, T2 in PBS and formulated T2 was stained with 2.5\% (v/v) SYBR green I and examined under high magnification using fluorescence microscopy. Non-formulated phage (T2 in PBS were well dispersed represented by well-spaced bright particles. In contrast, the formulated phage were associated with $\gamma$-PGA (Figure 9), as formulated phages are seen to aggregate in characteristic clumps within and around $\gamma$-PGA.

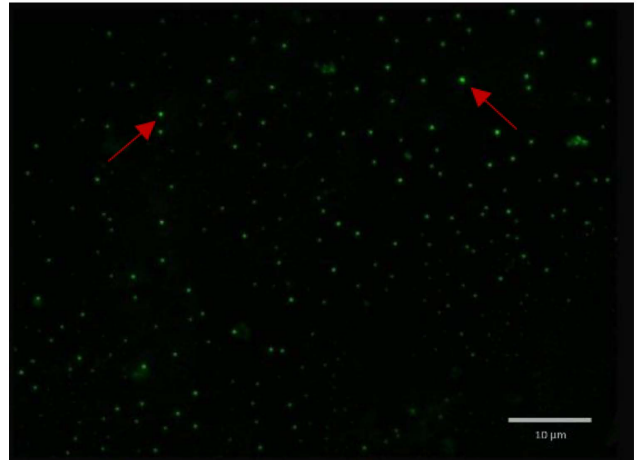

(a)

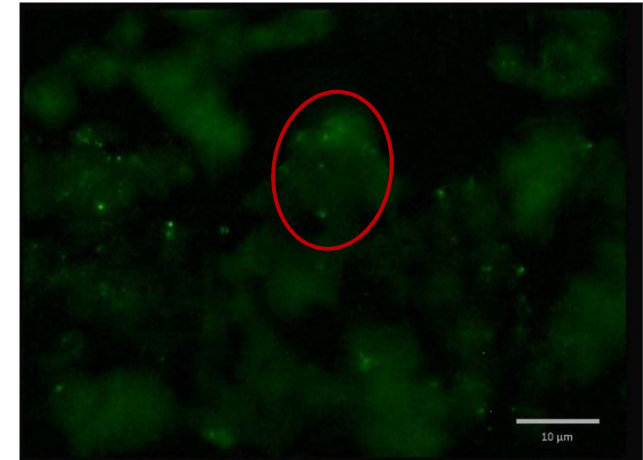

(b)

Figure 9. SYBR green I $(2.5 \% \mathrm{v} / \mathrm{v})$ stained samples were investigated under Fluorescence Microscopy: (a) T2 in PBS (non-formulated phage) well dispersed as represented by well-spaced bright particles as shown by red arrows; (b) T2 formulated with $\gamma$-PGA, clearly virion particles are associated with $\gamma$-PGA as shown within red ring. Scale bar, $10 \mu \mathrm{m}$.

\section{Discussion}

Poly- $\gamma$-glutamic acid ( $\gamma$-PGA) is a biodegradable, biocompatible and non-toxic polymer. These characteristics make it a particularly attractive polymer for a wide range of potential applications in the biomedical and environmental industries. Their solubility in water is also a characteristic that makes it well suited for these applications compared to other polymers that are soluble only in organic solvents, some of which may have harmful environmental and biological implications. The ability of $\gamma$-PGA to protect and effectively deliver a wide range of drugs to their target site has been studied extensively $[1,25,26]$. In addition, the polymer has been used in the protection and delivery 
of genetic materials and vaccines [1]. Recently, $\gamma$-PGA was shown to effectively protect probiotic bacteria from the effect of harsh environmental conditions for effective storage and enhanced delivery to their host [9]. However, the use of these polymers to protect active phage particles from harsh environmental conditions has previously not been studied.

Phages are considered to have possible applications as an alternative or as a complement to antibacterials for humans and animals or as chemical disinfectants on hands, plant leaves and hard surfaces [24,27]. There are many advantages of using phages as an alternative to antibiotics or for biological control. One major example is that phages are specific in their action and if used as disinfectants can help to stop the spread of a particular pathogen in the environment without interfering with normal microflora. The ability of phages to replicate rapidly [15-18] means that they do not need to be applied in high amounts as even a small number of phage particles can be highly effective if protected from harsh environmental conditions. Moreover, phages and their bacterial hosts are an attractive alternative among possible model systems as they allow facile manipulation of conditions such as: host, population parameters, transmission rates and environmental conditions [28]. Phages are not especially demanding with regard to facilities or equipment and are rapidly regenerated without any difficulty and at a relatively low cost [29]. However, the ability of phage to persist for extended periods is limited by many factors including UV irradiation, temperature, acidity and desiccation $[21,23,24]$.

In this work, the survival rates of formulated and non-formulated phage were evaluated via a series of time course experiments under different adverse conditions. This study demonstrated that $\gamma$-PGA can efficiently protect MS2 and T2 phage in environments with temperatures as high as $60^{\circ} \mathrm{C}$. The observed data shows that $\gamma$-PGA increases survival of MS2 bacteriophage when it is exposed to increasing temperatures including $37^{\circ} \mathrm{C}, 50^{\circ} \mathrm{C}$ and $60^{\circ} \mathrm{C}$ (Figure 4). A previous study using the integrated virus detection system (IVDS) found MS2 phages can be detected when temperatures are increased to $63^{\circ} \mathrm{C}$ for half an hour, but longer exposure or increasing temperature results in a quick decrease in detectable MS2 particles [30]. However, we show here that MS2 phages without $\gamma$-PGA were detected even after $24 \mathrm{~h}$ of exposure to $60^{\circ} \mathrm{C}$ but with very low viable number. When $\gamma$-PGA was present, this loss in viability was less rapid. This finding suggests that protection might occur through physical protection of the virus particle as $\gamma$-PGA mask the phage and decrease the heat levels reaching viral particles, or the high amino acid content in $\gamma$-PGA may be favourable for virion survival. The biopolymer $\gamma$-PGA is stable at all temperatures used in this study as it has a melting point as high as $206^{\circ} \mathrm{C}$. To enhance $\gamma$-PGA production, Bacillus licheniformis can be heated to $50{ }^{\circ} \mathrm{C}$, which actually increases $\gamma$-PGA yield by $66 \%$ [31]. This suggests a role of $\gamma$-PGA production in the cell as a heat-shock response. As $\gamma$-PGA protects the host from heat, it also then may protect MS2 from heat in similar manner, due to its chemical and physical properties shielding the viral capsid and delaying denaturation. An interesting finding is that the protective effect of $\gamma$-PGA is not dose-dependent, practically, at $50{ }^{\circ} \mathrm{C}$. The data suggests $1 \% \gamma$-PGA may be more protective than $2 \% \gamma$-PGA in case of MS2 phage. It could be that higher concentrations of $\gamma$-PGA may prevent interaction of phage virions with the bacterial host. Although at this point this is only a qualitative observation and requires further investigation.

The phages T4 and T2 are members of the Myoviriadae family and are stable at a pH range of $5-9$, below or above this range phage survival is significantly decreased [21]. Survival of formulated $\mathrm{T} 2$ phage was remarkably improved at different $\mathrm{pH}$ values. All experiments at different $\mathrm{pH}$ values were evaluated at $0,24,48$ and $72 \mathrm{~h}$. the $\mathrm{pH}$ value of 3 was also examined at $0,1,2,3$ and $24 \mathrm{~h}$, there was no observation of any survival rate after $48 \mathrm{~h}$, from either formulated or non-formulated phage. The polymer used in our work is a $\mathrm{pH}$ sensitive polymer. In highly acidic environments the polymer is stable as it forms an alpha-helical structure. This conformational change which is thought to allow phage to be effectively "wrapped up" or shielded by the now, filament-like polymer from acidic environments. This effect has already been investigated by similar study; Bhat and co-workers demonstrated that formulating probiotic bacteria with $\gamma$-PGA increases the survival rate remarkably 
in extreme acidic environment [9]. This biopolymer is able to form different engineering structures at different $\mathrm{pH}$. Ho et al. (2006) observed that $\gamma$-PGA forms a linear random-coil formation at neutral $\mathrm{pH}$ [32]. For that reason, the protective effect of $\mathrm{pH} 11$ was not fully understood. It might be the linear random-coil formation physically masks the phage and shields it from the harsh surrounding environment. It was also observed that with longer duration of the $\mathrm{pH} 11$ experiment the $\mathrm{pH}$ level decreased, especially on the third day of exposure (data not shown). However, further investigations as to the possible buffering effect of $\gamma$-PGA need to be performed.

The difference in survival rates between formulated and non-formulated T2 phage was significant $(\mathrm{P}<0.05)$ at all $\mathrm{pH}$ values tested. However, there were no statistically significant results in the reduction of MS2 phage viability with or without $\gamma$-PGA formulation (results not shown). Phage MS2 is stable over a wide range of $\mathrm{pH}$ values. Previous work has found MS2 is stable under strong acidic conditions as low as $\mathrm{pH} 1.4$ [30]. This may explain why we did not observe a difference in formulated and non-formulated MS2 viability.

Iriarte $e t$ al. reported that phage viability is clearly affected by exposure to UV irradiation as it causes lesions in DNA, which consequently obstruct RNA transcription and DNA replication [24]. Formulated phage showed better survival after exposure to UV irradiation compared to non-formulated phage. Perhaps $\gamma$-PGA can protect the phage from UV irradiation by either masking the phage or due to the turbidity of the solution which refracts the UV radiation.

The mechanism behind the protective effect of $\gamma$-PGA on phage is difficult to elucidate. Phage stained with SYBER green 1 was used to investigate the interaction between the phage and $\gamma$-PGA, as the dye is a nucleic-acid stain binding to the genomic DNA of the phage. The resulting complex absorbs blue light and emits green light as shown in (Figure 9). However, as both phage and $\gamma$-PGA are negatively charged, electrostatic interactions may not be the mechanism behind their interaction. Divalent cations such as $\mathrm{Ca}^{2+}$ and $\mathrm{Mg}^{2+}$ may influence the binding kinetics of MS2. Pham et al. discovered $\mathrm{Ca}^{2+}$ increased attachment efficacies of MS2 to Suwannee River Natural Organic Matter (SRNOM)-coated silica surfaces by up to seventeen times compared to $\mathrm{Mg}^{2+}$ [33]. The authors also showed the adsorption of $\gamma$-PGA, which was one of the amino-acid residues found on the surface of MS2 capsids present on SRNOM-coated surfaces. This suggests that when $\gamma$-PGA and phage are exposed to divalent cations such as $\mathrm{Ca}^{2+}, \mathrm{MS} 2$ has a higher affinity to $\gamma$-PGA due to the carboxylic functional groups found on MS2 and $\gamma$-PGA surfaces, allowing salt ions to form cation bridges between phage and $\gamma$-PGA, as the negative charge density is greater on $\gamma$-PGA than on phage [34]. Salt ions could also have a role, by partially neutralizing the negative charges between phage and $\gamma$-PGA, increasing the chance of electrostatic interactions. The interaction between $\gamma$-PGA and the phage may explain the protective effect of $\gamma$-PGA on phage through masking the phage and then may protect it from harsh conditions.

Our work presented in this study with formulated T-even phage and MS2 phage has provided very interesting results, as it is clear that phage stability can be increased by $\gamma$-PGA. This may have many implications as $\gamma$-PGA could be used to increase the stability of therapeutic bacteriophages, or even other types of virus which are clinically relevant in disease treatment. One major drawback of virus-based vectors is their lack of stability [35], so the use of $\gamma$-PGA may widen the range of viruses that could be studied for therapeutic or non-therapeutic benefit. Increasing the range of clinically-relevant viruses could have wide implications for medicine, as viruses can be used for many clinical applications including gene therapy, drug delivery and as chemotherapeutic antibacterial agents. Increasing the stability of viruses could therefore have implications on almost every area of biomedical science.

However, further study into the mechanism of protective effects should focus on the interaction between the phage and the polymer. This could then be used to enhance the association, and therefore the protective effect. Further experimental parameters which are important in environmental survival of viral particles could also be investigated such as humidity and salinity. 


\section{Material and Methods}

\section{1. $\gamma$-PGA Production, Purification and Characterization}

The biopolymer $\gamma$-PGA was produced and isolated as previously described [36]. The obtained polymer was identified by Fourier Transforming Infrared Spectroscopy (FTIR) (Genesis II, Mattson, Geneseo, NY, USA) and Nuclear Magnetic Resonance $\left({ }^{1} \mathrm{H}-\mathrm{NMR}\right.$, Bruker Ultrashield AVANCE II $600 \mathrm{MHz}$, Rheinstetten, Germany). ${ }^{1} \mathrm{H}-\mathrm{NMR}$ Spectra were obtained with 64 scans, an $11 \mathrm{~ms}$ pulse width, and a $2.65 \mathrm{~s}$ acquisition time. The data was collected and analyzed using Bruker TOPSPIN 2.0 software, Deuterium oxide $\left(\mathrm{D}_{2} \mathrm{O}\right)$ was used as a solvent. The number average molecular mass $\left(\mathrm{M}_{n}\right)$ was determined by conventional aqueous based gel permeation chromatography (GPC) at Smithers Rapra in Shrewsbury, UK. An MZ Hema guard plus $2 \times$ Hema Linear column (Cognis Performance Chemicals Ltd., Southampton, UK) was used for analysis. The GPC experiments were carried out in $0.2 \mathrm{M} \mathrm{NaNO}_{3}, 0.01 \mathrm{M} \mathrm{NaH}_{2} \mathrm{PO}_{4}$, at $\mathrm{pH} 7$, with a flow rate of $1 \mathrm{~mL} / \mathrm{min}$ at $30{ }^{\circ} \mathrm{C}$. The data was collected and analyzed using Polymer Laboratories "Cirrus 3.0" software.

\subsection{Bacterial Strains and Phages}

Wild type E. coli (NCIMB 11291) was used as an host for T4 and T2 bacteriophages, and E. coli (NCIMB 9481) was used as an host for MS2 phage. B. subtilis natto (ATCC 15245) was used for $\gamma$-PGA production. All bacteria strains and phages and were obtained from the National Collection of Industrial and Marine Bacteria (NCIMB, Aberdeen, UK).

\subsection{Phage Amplification and Titration}

Phage was amplified and the titrations were calculated using a standard overlay technique as previously reported [23].

\subsection{Phage and $\gamma$-PGA Formulation}

Appropriate amounts of $\gamma$-PGA dissolved in Phosphate Buffer Saline (PBS) were autoclaved at $110^{\circ} \mathrm{C}$ for $30 \mathrm{~min}$ as previously reported [10]. Then $0.5 \mathrm{~mL}$ of a phage suspension containing $2.2 \times 10^{8}$ or $10^{7} \mathrm{PFU} / \mathrm{mL}$, was mixed with $4.5 \mathrm{~mL}$ of different concentrations of sterilized $\gamma$-PGA to obtain final concentration of $0.1,1$ and $2 \%$ of $\gamma$-PGA and $10^{7}$ or $10^{6} \mathrm{PFU} / \mathrm{mL}$ of phage. Each dilution was then incubated at room temperature for $1 \mathrm{~h}$ before use. The term formulated phage means phage with $\gamma$-PGA, and non-formulated phage means phage without $\gamma$-PGA, just in PBS.

\subsection{Effect of Elevated Temperature}

Formulated and non-formulated phage samples were kept for $3 \mathrm{~d}$ in an Eppendorf tube at different temperatures. MS2 phage were kept at 22,37 and $50{ }^{\circ} \mathrm{C}$ and evaluated on each day of exposure while T-even phages were kept at 22, 50, 60 and $70^{\circ} \mathrm{C}$ and evaluated after 1, 2, 3, 4 and $24 \mathrm{~h}$ using a standard overlay technique as previously described [23], which represent viability, infectivity or survival rate of the phages.

\subsection{Effect of UV Irradiation on Phage Viability}

Initially, $1 \mathrm{~mL}$ of formulated and non-formulated phage in 6 wells tissue culture plates were placed into a UV Crosslinker (UVP®95-0174-01 Model CL-1000, 8-watt, 254 nm Shortwave, 115V Ultra-Violet Products, Cambridge, UK). Samples were exposed to UV irradiation for 10 min and evaluated for phage viability after 5 and 10 min using a standard overlay technique as previously described [23]. 


\subsection{Effect of Different $p H$ Values on Phage Longevity}

The $\mathrm{pH}$ of the solutions ( $0.85 \%$ isotonic saline, BR0053 Oxoid Ltd., Basingstoke, UK) was adjusted by adding $0.1 \mathrm{M} \mathrm{HCl}$ or $0.1 \mathrm{M} \mathrm{NaOH}$ to obtain $\mathrm{pH}$ of $\sim 3,4,6.4$ and 11 . Then $0.5 \mathrm{~mL}$ of formulated and non-formulated phage samples at $2.2 \times 10^{7} \mathrm{PFU} / \mathrm{mL}$, were added to $4.5 \mathrm{~mL}$ of each different $\mathrm{pH}$ solutions to a final phage concentration of $2.2 \times 10^{6} \mathrm{PFU} / \mathrm{mL}$ and adjusted again to the desired $\mathrm{pH}$. Samples were tested after 0, 24, 48, and $72 \mathrm{~h}$. However, for $\mathrm{pH} 3$ the samples were tested after $0,0.5,1$, 2,3 and $24 \mathrm{~h}$.

\subsection{Fluorescence Microscopy with SYBR 1 to Determine $\gamma$-PGA-Phage Interaction}

Phages were investigated under fluorescence microscopy (Olympus BX61 Fluorescent microscope, Tokyo, Japan) as in a previously described study [37]. $20 \mu \mathrm{L}$ of formulated and non-formulated T2 were deposited on slides and stained with SYBR green I (ABgene, Epsom, UK). The resulting samples were examined immediately under fluorescence microscopy. Non-formulated T2 was used as a control.

\subsection{Survival Experiments and Statistical Analyses}

All samples from heat, UV and different $\mathrm{pH}$ experiments were evaluated using a standard overlay technique [23]. The data ta obtained from different experiments in this study were converted to logarithmic values, the resulting values transformed to survival percentages relative to time zero using MS Excel to give the reader clearer image. Survival levels in formulated and non-formulated phage samples were compared using the Student's T-test and a one-way analysis of variance (ANOVA) in the statistical package GraphPad Prism version 6.03 (GraphPad Software, Inc., La Jolla, CA, USA). $P$ value $\leqslant 0.05$ was considered to be statistically significant.

\section{Conclusions}

The present study suggests that the biodegradable polymer formulation used in this work may be used for better bio-control using phages. The data obtained revealed that $\gamma$-PGA does indeed have a protective effect on phage. It was found that $\gamma$-PGA protected $\mathrm{T}$ even phages from UV damage, damage due to exposure to high temperatures and the exposure to extremes of $\mathrm{pH}$ values. The other model phage used in this experiment, MS2, was naturally resistant to varying $\mathrm{pH}$, so the protective effect for $\mathrm{pH}$ could not be determined. This result has many wider implications in the field of medicine, and other industries where viruses can be of use, such as agriculture. This is because viruses including bacteriophage can have therapeutic effects. The complexing of $\gamma$-PGA with viruses which are being studied in gene therapy may increase the viability of the virus in the human body, increasing the effectiveness of the therapy, could lead to a significant improvement in these treatment modalities.

Acknowledgments: This study was financially supported by the Iraqi cultural attaché. In addition, we thank Iwona Kwiecien for her work on ${ }^{1} \mathrm{H}-\mathrm{NMR}$ analysis.

Author Contributions: Ibrahim Khalil and Victor Irorere were responsible for the production, recovery and characterization of Poly- $\gamma$-glutamic acid. Ibrahim Khalil and Jessica Mason were responsible for the protection of bacteriophage by Poly- $\gamma$-glutamic acid. Ibrahim Khalil, Victor Irorere and Marek Kuwalkzuk were involved in the characterization of Poly- $\gamma$-glutamic acid and interpretation of data from polymer characterization. Alan Burns and Iza Radecka conceived the project with the long term aim of protecting therapeutic payloads such as viruses. Martin Khechara and Iza Radecka were the main persons involved in the planning and supervision of the project.

Conflicts of Interest: The authors declare no conflict of interest.

\section{References}

1. Ogunleye, A.; Bhat, A.; Irorere, V.U.; Hill, D.; Williams, C.; Radecka, I. Poly- $\gamma$-glutamic acid: Production, properties and applications. Microbiology 2015, 161, 1-17. [CrossRef] [PubMed]

2. Shih, I.L.; Van, Y.T. The production of poly-(gamma-glutamic acid) from microorganisms and its various applications. Bioresour. Technol. 2001, 79, 207-225. [CrossRef] 
3. Ashiuchi, M. Microbial production and chemical transformation of poly- $\gamma$-glutamate. Microb. Biotechnol. 2013, 6, 664-674. [CrossRef] [PubMed]

4. Manocha, B.; Margaritis, A. Controlled release of doxorubicin from doxorubicin/-polyglutamic acid ionic complex. J. Nanomater. 2010, 2010. [CrossRef]

5. Sung, M.H.; Park, C.; Kim, C.J.; Poo, H.; Soda, K.; Ashiuchi, M. Natural and edible biopolymer poly-gamma-glutamic acid: Synthesis, production, and applications. Chem. Rec. 2005, 5, 352-366. [CrossRef] [PubMed]

6. Wang, X.; Uto, T.; Akagi, T.; Akashi, M.; Baba, M. Poly( $\gamma$-glutamic acid) nanoparticles as an efficient antigen delivery and adjuvant system: Potential for an aids vaccine. J. Med. Virology 2008, 80, 11-19. [CrossRef] [PubMed]

7. Akagi, T.; Matsusaki, M.; Akashi, M. Pharmaceutical and medical applications of poly-gamma-glutamic acid. In Amino-Acid Homopolymers Occurring in Nature; Springer: Berlin, Germany, 2010; pp. 119-153.

8. Akagi, T.; Kaneko, T.; Kida, T.; Akashi, M. Preparation and characterization of biodegradable nanoparticles based on poly ( $\gamma$-glutamic acid) with 1-phenylalanine as a protein carrier. J. Control. Release 2005, 108, $226-236$. [CrossRef] [PubMed]

9. Bhat, A.R.; Irorere, V.U.; Bartlett, T.; Hill, D.; Kedia, G.; Charalampopoulos, D.; Nualkaekul, S.; Radecka, I. Improving survival of probiotic bacteria using bacterial poly- $\gamma$-glutamic acid. Int. J. Food Microbiol. 2015, 196, 24-31. [CrossRef] [PubMed]

10. Bhat, A.; Irorere, V.; Bartlett, T.; Hill, D.; Kedia, G.; Morris, M.; Charalampopoulos, D.; Radecka, I. Bacillus subtilis natto: A non-toxic source of poly- $\gamma$-glutamic acid that could be used as a cryoprotectant for probiotic bacteria. AMB Expr. 2013, 3, 1-9. [CrossRef] [PubMed]

11. Courchesne, N.M.; Parisien, A.; Lan, C.Q. Production and application of bacteriophage and bacteriophage-encoded lysins. Recent Pat. Biotechnol. 2009, 3, 37-45. [CrossRef] [PubMed]

12. Sulakvelidze, A.; Alavidze, Z.; Morris, J.G. Bacteriophage therapy. Antimicrob. Agents Chemother. 2001, 45, 649-659. [CrossRef] [PubMed]

13. Jassim, S.A.; Limoges, R.G. Natural solution to antibiotic resistance: Bacteriophages "the living drugs". World J. Microbiol. Biotechnol. 2014, 30, 2153-2170. [CrossRef] [PubMed]

14. Sillankorva, S.; Neubauer, P.; Azeredo, J. Isolation and characterization of a t7-like lytic phage for pseudomonas fluorescens. BMC Biotechnol. 2008, 8, 1-11. [CrossRef] [PubMed]

15. Tanji, Y.; Shimada, T.; Yoichi, M.; Miyanaga, K.; Hori, K.; Unno, H. Toward rational control of escherichia coli o157: H7 by a phage cocktail. Appl. Microbiol. Biotechnol. 2004, 64, 270-274. [CrossRef] [PubMed]

16. Sheng, H.; Knecht, H.J.; Kudva, I.T.; Hovde, C.J. Application of bacteriophages to control intestinal escherichia coli o157: H7 levels in ruminants. Appl. Environ. Microbiol. 2006, 72, 5359-5366. [CrossRef] [PubMed]

17. Sherman, M. Bacteriophages: Beyond antibiotics. US Pharmacist 2008, 33, 46-51.

18. Viazis, S.; Akhtar, M.; Feirtag, J.; Diez-Gonzalez, F. Reduction of escherichia coli o157: H7 viability on hard surfaces by treatment with a bacteriophage mixture. Int. J. Food Microbiol. 2011, 145, 37-42. [CrossRef] [PubMed]

19. Abedon, S.T.; Kuhl, S.J.; Blasdel, B.G.; Kutter, E.M. Phage treatment of human infections. Bacteriophage 2011, 1, 66-85. [CrossRef] [PubMed]

20. Stone, R. Bacteriophage therapy. Stalin's forgotten cure. Science 2002, 298, 728-731. [CrossRef] [PubMed]

21. Jonczyk, E.; Klak, M.; Miedzybrodzki, R.; Gorski, A. The influence of external factors on bacteriophages-Review. Folia Microbiol Praha 2011, 56, 191-200. [CrossRef] [PubMed]

22. Bryant, S.; Rahmanian, R.; Tam, H.; Zabetian, S. Effects of microwave irradiation and heat on $\mathrm{t} 4$ bacteriophage inactivation. J. Exp. Microbiol. Immunol. 2007, 11, 66-72.

23. Baines, B. Comparison of the effects of microwave irradiation and heat treatment of $\mathrm{t} 4$ and $\mathrm{t} 7 \mathrm{bacteriophage.}$ J. Exp. Microbiol. Immunol. 2005, 7, 57-61.

24. Iriarte, F.; Balogh, B.; Momol, M.; Smith, L.; Wilson, M.; Jones, J. Factors affecting survival of bacteriophage on tomato leaf surfaces. Appl. Environ. Microbiol. 2007, 73, 1704-1711. [CrossRef] [PubMed]

25. Akao, T.; Kimura, T.; Hirofuji, Y.S.; Matsunaga, K.; Imayoshi, R.; Nagao, J.; Cho, T.; Matsumoto, H.; Ohtono, S.; Ohno, J.; et al. A poly (gamma-glutamic acid)-amphiphile complex as a novel nanovehicle for drug delivery system. J. Drug Target. 2010, 18, 550-556. [CrossRef] [PubMed] 
26. Karmaker, S.; Saha, T.K.; Yoshikawa, Y.; Yasui, H.; Sakurai, H. A novel drug delivery system for type 1 diabetes: Insulin-mimetic vanadyl-poly(gamma-glutamic acid) complex. J. Inorg. Biochem. 2006, 100, 1535-1546. [CrossRef] [PubMed]

27. Khairnar, K.; Raut, M.P.; Chandekar, R.H.; Sanmukh, S.G.; Paunikar, W.N. Novel bacteriophage therapy for controlling metallo-beta-lactamase producing pseudomonas aeruginosa infection in catfish. BMC Veterinary Res. 2013, 9. [CrossRef] [PubMed]

28. Dennehy, J.J. Bacteriophages as model organisms for virus emergence research. Trends Microbiol. 2009, 17, 450-457. [CrossRef] [PubMed]

29. Grabow, W. Bacteriophages: Update on application as models for viruses in water. Water SA 2004, 27, 251-268. [CrossRef]

30. Wick, C.H.; Elashvili, I.; McCubbin, P.E.; Birenzvige, A. Determination of ms2 Bacteriophage Stability at High Temperatures Using the Integrated Virus Detection System (IVDS); DTIC Document; Aberdeen Proving Ground: Aberdeen, MD, USA, 2005.

31. Wei, X.; Tian, G.; Ji, Z.; Chen, S. A new strategy for enhancement of poly- $\gamma$-glutamic acid production by multiple physicochemical stresses in bacillus licheniformis. J. Chem. Technol. Biotechnol. 2015, 90, 709-713. [CrossRef]

32. Ho, G.H.; Ho, T.I.; Hsieh, K.H.; Su, Y.C.; Lin, P.Y.; Yang, J.; Yang, K.H.; Yang, S.C. Г-polyglutamic acid produced by bacillus subtilis (natto): Structural characteristics, chemical properties and biological functionalities. J. Chin. Chem. Soc. 2006, 53, 1363-1384. [CrossRef]

33. Pham, M.; Mintz, E.A.; Nguyen, T.H. Deposition kinetics of bacteriophage ms2 to natural organic matter: Role of divalent cations. J. Colloid Interface Sci. 2009, 338, 1-9. [CrossRef] [PubMed]

34. Stanley, N.R.; Lazazzera, B.A. Defining the genetic differences between wild and domestic strains of bacillus subtilis that affect poly- $\gamma$-dl-glutamic acid production and biofilm formation. Mol. Microbiol. 2005, 57, 1143-1158. [CrossRef] [PubMed]

35. Folimonov, A.S.; Folimonova, S.Y.; Bar-Joseph, M.; Dawson, W.O. A stable RNA virus-based vector for citrus trees. Virology 2007, 368, 205-216. [CrossRef] [PubMed]

36. Kedia, G.; Hill, D.; Hill, R.; Radecka, I. Production of poly- $\gamma$-glutamic acid by bacillus subtilis and bacillus licheniformis with different growth media. J. Nanosci. Nanotechnol. 2010, 10, 5926-5934. [CrossRef] [PubMed]

37. Noble, R.T.; Fuhrman, J.A. Use of sybr green i for rapid epifluorescence counts of marine viruses and bacteria. Aquatic Microb. Ecology 1998, 14, 113-118. [CrossRef]

(C) 2016 by the authors; licensee MDPI, Basel, Switzerland. This article is an open access article distributed under the terms and conditions of the Creative Commons by Attribution (CC-BY) license (http:/ / creativecommons.org/licenses/by/4.0/). 